\title{
Työttömien terveyspalvelujen kehittäminen monitahoarvioinnin viitekehyksessä
}

\begin{abstract}
Abstrakti
Terveydenhuolto on yksi verkostokumppani työttömien monialaisessa työelämävalmiuksien tukemisessa. Tämän artikkelin tavoitteena on arvioida työttömien terveydenhuollon kehittämistä eri toimijoiden näkökulmista monitahoarvioinnin viitekehyksessä. Aineisto kerättiin Työterveyslaitoksen osahankkeessa Työttömien terveyspalvelujen sisällön ja rakenteen kehittäminen, joka oli vuosina 20152018 osa ESR:n rahoittamaa hanketta Party - Parempaa työ- ja toimintakykyä. Arviointiaineisto on laadullinen ja moninäkökulmainen. Arviointikriteeristö muodostui käytännönläheisesti. Tulosten mukaan työttömien terveyspalvelujen yhteistyöverkoston toiminta edellyttää pysyviä toimintamalleja ja moniammatillisen yhteistyön tiivistämistä. Keskeisenä kehittämiskohteena on kokonaisvaltainen tiedon koordinointi ja asiakaslähtöisen yhteistyön kehittäminen sekä tasa-arvoisten terveyspalvelujen tuottaminen kaikille työikäisille. Asiakas tulee osallistaa omaan prosessiinsa ja huomioida yksiölliset palvelutarpeet. Lisäksi tarvitaan monitieteistä vaikuttavuustutkimusta palvelujen kehittämiseen.
\end{abstract}

\section{Johdanto}

Suomessa työttömät ovat tyytymättömämpiä terveyspalveluihin kuin muissa EU-maissa keskimäärin (OECD 2017). Myös terveyserot ovat kasvaneet, vaikka tuloerot ovat OECD-maiden pienimmät (Koskinen \& Martelin 2013). Tyytymättömyys johtuu muun muassa pitkistä odotusajoista hoitoon, kun samaan aikaan työterveyshuollon piirissä olevat työlliset saavat pääosin nopeaa palvelua. Lisäksi työttömien terveystarkastukset ja työkyvyn arviointiin liittyvät toimenpiteet vaihtelevat paljon eri kunnissa (Sinervo \& Hietapakka 2013).

Kunnalla on lakisääteinen velvollisuus järjestää terveysneuvontaa ja terveystarkastuksia myös opiskelu- tai työterveyshuollon ulko- puolelle jääville nuorille ja työikäisille (Terveydenhuoltolaki 2010). Myös väestönäkökulman ja terveydenhuoltolain (L 1326/2010 12 §) mukaan kunnan on seurattava asukkaidensa terveyttä ja hyvinvointia sekä niihin vaikuttavia tekijöitä väestöryhmittäin. Työttömien terveyspalveluihin kuuluvat ennaltaehkäisevien terveyspalvelujen lisäksi pääosin lääkärien tekemät työ- ja toimintakyvyn arvioinnit. Keskeinen elementti työttömien terveyspalvelujen toteuttamisessa on monialainen verkostoyhteistyö, johon kuuluu useiden asiantuntijoiden tuottaman tiedon kokoaminen ja käyttö. Työttömien kohdalla kuntoutustarpeen arvioinnissa on puutteita ja ennaltaehkäisevissä palveluissa vaihtelevuutta. Yksi syy tähän on osaamisen puute perusterveydenhuollossa. 
(Kerätär 2016.) Verkostoyhteistyöhön pohjautuva systemaattinen toiminta on haasteellista monisektorisessa palvelujärjestelmässä. Tämän vuoksi tarvitaan kokonaisprosessin koordinointia sekä terveydenhuollon sisällä toimivaa asiakkaan prosessia edistävää koordinaattoria. (Kerätär 2016; Lappalainen 2017a).

Toimivalla työttömien terveydenhuollolla tuetaan työttömien työelämävalmiuksia. Työttömien työelämävalmiuksien tukemisen verkosto toimii itseorganisoituvasti, eikä verkostolla ole selvää johtajaa tai koordinoijaa (Lappalainen 2017a). Verkoston pitäisi toimia asiakasta varten ja perustua yhteiseen tavoitteeseen. Lisäksi perustana tulisi olla viranomaisten välinen luottamus ja yhteistyö. (Virtanen 1999). Työttömien työelämävalmiuksien tukemiseen liittyvässä viranomaisyhteistyössä haasteena on yhteistyö yli organisaatiorajojen. Varhainen tunnistaminen, prosessin toimivuus ja vastuunjaot vaativat kehittämistä (Lappalainen 2017a).

Suomen hallituksen tavoitteena on työllisyysasteen nostaminen (Hallituksen toimintasuunnitelma 2019). Työelämäosallisuuden lisäämisen yhtenä keinona on työ- ja toimintakykyä tukevan palvelun kehittäminen. Tämä edellyttää asiakastarpeisiin perustuvan varhaisen tunnistamisen, suunnitelman laatimisen, kuntoutustarpeen arvioinnin ja suunnitelmien toteuttamisen kehittämistä.

Työttömien terveydenhuoltoa on kehitetty pääosin hankkeiden kautta ja tutkittu tieto on vähäistä. Hankkeiden antia ja eri toimijoiden näkökulmia ei myöskään ole koottu yhteen. Tämän artikkelin tavoitteena on arvioida työttömien terveydenhuollon kehittämistä eri toimijoiden näkökulmista monitahoarvioinnin viitekehyksessä. Arviointi kokoaa tietoa työttömien terveyspalvelujen edelleen kehittämisen tueksi. Aineisto kerättiin Työterveyslaitoksen osahankkeessa Työttömien terveyspalvelujen sisällön ja rakenteen kehittäminen, joka oli osa ESR-rahoitteista hanketta Party - Parempaa työ- ja toimintakykyä. Muut hankkeen osatoimijat päätoteuttaja Rauman kaupungin lisäksi olivat Eura, Eurajoki, Turku, Salo, Somero,
Taitokunto ja Vates-säätiö. Hanke toteutettiin vuosina 2015-2018. (Party-hanke 2018; TTPhanke 2018.) Kirjoittajat toimivat hankkeen sisäisinä arvioijina ja työpajojen vetäjinä. Lisäksi toinen kirjoittajista toimi yhtenä hankkeen kouluttajana ja koulutusten järjestäjänä. Kirjoittajat eivät kuitenkaan tehneet varsinaista kehittämistyötä asiakkaiden parissa kentällä.

\section{Työttömien terveyspalveluiden kehittäminen}

Työttömät käyttävät pääasiassa kunnallisia terveyskeskuspalveluja, kun taas työsuhteessa olevat henkilöt ovat pääosin työnantajan kustantaman työterveyshuollon piirissä. Terveydenhuoltolaki (1326/2010, §13) velvoittaa kunnat järjestämään ennaltaehkäisevät terveyspalvelut työterveyshuollon ja opiskeluterveydenhuollon ulkopuolella oleville työikäisille. Näihin sisältyvät ensinnäkin terveydenhoitajien tekemät työttömien terveystarkastukset, jotka ovat keskeinen osa työttömille suunnattuja terveyspalveluja (STM 2011). Toiseksi työttömien terveyspalveluihin liittyvät työ- ja toimintakyvyn arvioinnit, jotka tapahtuvat pääasiassa lääkärin vastaanotolla. Kolmas elementti työttömien terveyspalveluissa on monialainen yhteistyö ja verkosto-osaaminen, jota palvelujen toteuttaminen onnistuneesti edellyttää (Lappalainen 2017a; Saikku 2010).

Työttömien terveyspalveluihin liittyvät sekä ennaltaehkäisevät että sairaanhoidolliset palvelut. Terveystarkastukset eivät ole riittävä toimenpide työkyvyn ja kuntoutustarpeen arvioimiseksi, vaikka ne toimivatkin tärkeänä osana asiakkaan palveluketjussa (Oivo \& Kerätär 2018). Jos terveystarkastus on irrallinen toimenpide perusterveydenhuollossa, sen merkitys työttömän työ- ja toimintakyvyn tukemiseen on vähäinen (Lappalainen ym. 2018; Saikku 2012).

Työttömien terveyspalveluihin liittyy erityispiirteitä, kuten työkyvyn arvioinnin tarve, jotka edellyttävät moniammatillista työskentelyä (Kerätär 2016). Varsinkin pitkäaikais- 
työttömät hakeutuvat terveyspalveluihin tarpeeseensa nähden vähän, eikä heidän palvelutarvettaan välttämättä tunnisteta (Lappalainen ym. 2018).

Tehokkaat terveyspalvelut ovat sosiaalisen kestävyyden kannalta tärkeitä (STM 2011). Työttömät ovat heterogeeninen ryhmä ja heillä on erilaisia palvelutarpeita (Saikku 2010). Brussige ja kumppanit (2014) ovat osoittaneet, että terveyden edistäminen työmarkkinaohjelmien (mm. työkokeilut, tuettu työllistäminen, palkkatuki) avulla on mahdollista, mutta se vaatii sopimuksia, koordinaatiota ja kehittämistyötä eri sektoreiden toimijoiden kesken. Esimerkiksi Työhön-ryhmämenetelmä on todettu vaikuttavaksi menetelmäksi Suomessa (Vuori ym. 2005). Menetelmällä on myönteisiä vaikutuksia työllistymiseen, työvoiman ulkopuolelle päätymisen vähentämiseen sekä mielenterveyden kohentamiseen. (Vuori \& Toikkanen 2008; Vuori ym. 2005.) Hultin ja kollegoiden (2020) Cochrane-katsauksen mukaan terapeuttisia menetelmiä ja työnhakukoulutusta yhdistävillä vaihtoehdoilla on todennäköisesti pieni myönteinen vaikutus työllisyyden lisäämisessä. Terapeuttisilla interventioilla voi olla vaikutusta myös uudelleentyöllistymiseen. Katsauksessa oli mukana 15 eri maissa tehtyä satunnaistettua kontrolloitua tutkimusta (16 interventiota), joissa oli yhteensä 6397 työtöntä osallistujaa.

Palvelujen järjestämisen ja tuottamisen näkökulmasta on erotettava toisistaan työttömyyden uhan alla olevat, tilapäisesti työttömät, pitkäaikaistyöttömät ja pysyvästi työttömät (Taipale 2013), sillä heidän palvelutarpeensa poikkeavat toisistaan. Kerättären (2016) mukaan suurella osalla pitkäaikaistyöttömistä työkyky on merkittävästi heikentynyt. Syynä ovat etenkin mielenterveyden häiriöt, kuten ahdistuneisuus ja erilaiset pelkotilat. Työttömyys on voimakkaasti yhteydessä köyhyyteen, sosiaaliseen eristyneisyyteen, menetettyyn itsetuntoon, masennukseen, huonoon fyysiseen terveyteen sekä ennenaikaiseen kuolleisuuteen (Hammarström \& Janlert 2002; Böckerman \& Ilmakunnas 2008).
Moniammatillinen ja monisektorinen yhteistyö on keskeinen osa työttömän palveluprosessia (Saikku 2012). Monialaisessa verkostossa olevaa tietoa työttömän henkilön toimintakyvystä tulisi hyödyntää nykyistä enemmän, sillä yksipuolinen näkemys ei ole välttämättä riittävä. Moninaisten ongelmien tunnistaminen perinteisillä työkyvyn arvioinnin menetelmillä on hankalaa. Työkyvyn arvioinnissa tulisi käyttää kokonaisvaltaista, biopsykososiaalista terveyskäsitystä, jossa henkilön terveydentilaan liittyvien tekijöiden lisäksi otetaan huomioon myös ympäristö- ja yksilötekijöiden vaikutus. (Kerätär 2016.) Työttömien terveyden ja työkyvyn tukemisessa erilaisten osaamisten yhdistäminen on tärkeää, sillä yhden ammattilaisen näkemys jää liian suppeaksi. Esimerkiksi työvoimatoimistojen henkilöstöltä vaaditaan uusia taitoja ja osaamista palvelutarpeen tunnistamiseen (Brussige ym. 2014). Myös sosiaalihuollon rooli voi olla merkittävä työttömien terveyspalvelujen käynnistäjänä. Poliittisesti ajateltuna on tasa-arvoista käyttää yhteiskunnan resursseja työttömien erilaisiin ryhmiin eikä pelkästään heihin, jotka ovat pitkäaikaisesti työttömiä (Böckerman \& Ilmakunnas 2008).

Tutkimusta työttömien terveyspalvelujen kehittämisen näkökulmasta on vähän (katso kuitenkin Saikku \& Sinervo 2010; Lappalainen 2017a). Kehittämistyötä on tehty pääsääntöisesti hankkeiden kautta; esimerkiksi Pitkäaikaistyöttömien terveydenhuollon kehittämishankkeessa (Sinervo 2009; Niiranen ym. 2014; Niiranen ym. 2011), Party-hankkeessa (2015-2018) sekä OTE-kärkihankkeissa (20162018). Terveydeksi-hankkeessa (2016-2019) kokemuksia kerättiin työttömien terveystarkastuksista työttömien henkilöiden näkökulmasta. Näiden hankkeiden antia ei ole koottu yhteen. Pitkäaikaistyöttömien terveyspalveluita alettiin kehittää aiempaa laajemmin 2000luvun lopulla. Vuodesta 2006 lähtien kunnille on osoitettu lisämäärärahaa palvelujen kehittämiseen. Vuonna 2002 käynnistyi Työvoiman palvelukeskustoiminta TYP, joka on kunnan, TE-hallinnon ja Kelan yhteispalvelu vaikeasti 
työllistyville (Peltola \& Vuorento 2007). TYPtoiminnasta tuli lakisääteistä vuoden 2015 alussa. Työttömien terveyspalvelut ovat kehittyneet myönteiseen suuntaan, mutta kehittämistyötä tarvitaan yhä, jotta palvelut saataisiin tasapuolisesti toimimaan kaikkialla Suomessa. Kehittämistyötä tehtiin myös osana sote- ja maakuntauudistustyötä, kun tavoiteltiin aiempaa kokonaisvaltaisempia ja toimivampia ratkaisumalleja palvelukokonaisuuksiin (Mattila-Wiro \& Tiainen 2019).

Vaikka työttömien terveyspalvelujen ympärillä on ollut valtakunnallista ja etenkin alueellista kehittämistä pääosin hankkeiden kautta, puuttuu arviointi siitä, miten työttömien terveyspalveluita tulisi kehittää. Tämän tutkimuksen tavoitteena on arvioida työttömien terveydenhuollon kehittämistä ja koota tietoa eri toimijoiden näkökulmista monitahoarvioinnin viitekehyksessä.

\section{Monitahoarviointi näkökulmien yhdistäjänä ja arvioijana}

Monitahoarvioinnin juuret ovat 1980-luvulla, jolloin Zammuto (1984) sekä Connolly, Conlon ja Deutch (1980) pohtivat intressiryhmien roolia arviointiprosessissa. Monitahoarviointia ei voi yhdistää tiettyyn teoriaperinteeseen tai aikakauteen, vaan metodin kehittämiseen ovat vaikuttaneet erilaisten intressiryhmien arvioinnit (Vartiainen 2001). Vartiainen (2003) luokittelee intressiryhmien analyysin kuuluvan laajaan kokonaisuuteen teoreettisia lähestymistapoja, jotka suosivat konstruktivismia mieluummin kuin realismia ja pluralismia tai yksittäistä kuvaa todellisuudesta (Connolly ym. 1980). Vartiaisen (2003) mukaan tietoa ei voi irrottaa kontekstistaan, vaan on olemassa erilaisia sosiaalisia todellisuuksia, joita ei voida kuvata luonnonlaeilla tai kausaalisuhteina. Tieto rakentuu siinä yhteydessä, jossa henkilö toimii (Guba \& Lincoln 1989; Vartiainen 2001).

Vartiainen (1994) on suomentanut multiple constituency -malliin perustuvan arviointimetodin monitahoarvioinniksi, joka on kehitty- nyt käyttäjälähtöisen, konstruktivistisen, osallistuvan ja yhteistoiminnallisen arviointimallin lähtökohdista. Monitahoarvioinnissa avainryhmät konstruoivat toimintaympäristöään ja välittävät ympäristönsä rakenteita arviointitiedon keruun yhteydessä. Monitahoarviointi kiinnittää arviointiprosessiin tarkoituksenmukaiset avainryhmät ja tekee arvioinnista osallistavaa arviointia. Avainryhmien rooli on arviointiprosessissa tärkeä, mutta menetelmä ottaa kantaa myös arviointikohteen ja ympäristön vuorovaikutukseen sekä kerättävän informaation luonteeseen, avainryhmien osallistumiseen, kriteerien muodostamiseen sekä tulosten analyysiin. Monitahoarvioinnissa panostetaan arvioitavan kohteen ja sen taustojen mahdollisimman laajaan tuntemukseen. Keskeisenä ajatuksena on, että totuudenmukainen ja luotettava arviointitieto syntyy vain arviointikohteen laajan ja monipuolisen ymmärtämisen kautta. Tähän tarvitaan ilmiön teoreettista ja käytännöllistä haltuunottoa. (ChetkowYanoov 1992.)

Avainryhmien rooli voi olla monitahoarvioinnissa varsin erilainen. Vartiainen (2007) luokittelee avainryhmien roolin neljään arviointinäkökulmaan: 1) laaja-alaiseen, 2) neuvottelevaan, 3) sosiaalisesti oikeudenmukaiseen ja 4) evolutionaariseen. Tässä tutkimuksessa hyödynnetään laaja-alaista arviointinäkökulmaa, jossa korostetaan mahdollisimman monipuolisen informaation keräämistä eri lähteistä ja niiden analyyttistä yhdistämistä. Tällöin avainryhmien rooli tiedontuottajana korostuu. Laaja-alaisuudella saavutetaan monipuolinen kuva työttömien terveyspalvelujen kehittämisestä. Arviointi on formaalista arviointia, koska tarkoituksena on koota monitahoarvioinnilla tietoa työttömien terveyspalveluiden kehittämiseksi edelleen.

Tähän tutkimukseen sisällytettiin kaikki olennaiset avainryhmät, jotta työttömien terveydenhuollon kehittämisen arviointi olisi luotettavaa. Jokaisen avainryhmän tuottama tieto on merkityksellistä. Laaja-alainen arviointinäkökulma auttaa muodostamaan monipuolisten aineistojen kautta laajan kuvan arvioin- 
tikohteesta. Vartiaisen (2007) mukaan avainryhmien osallistumisen motiivit voidaan jakaa kahteen pääluokkaan: yksilölliset sekä sosiaaliset ja organisatoriset motiivit. Yksilöllisten motiivien suhteen avainryhmät haluavat varmistaa omat intressinsä ja tarpeensa evaluoinnissa. Sosiaalisten ja organisatoristen motiivien ollessa kyseessä avainryhmät haluavat tuoda esiin laajoja kulttuurisia tai sosiaalisia tekijöitä. Asiakkaat kuuluvat yksilöllisten motiivien ryhmään, koska he arvioivat saamaansa palvelua omasta näkökulmastaan. Terveystoimijat sekä kuntapäättäjät ja terveydenhuollon päättäjät edustavat sosiaalisten ja organisatoristen motiivien ryhmää. Hanketoimijat edustavat sekä yksilöllisten että sosiaalisen ja organisatoristen motivaatioiden ryhmää, sillä hanketoiminta muotoutuu aina jossain määrin yksilöllisten ominaisuuksien mukaan ja hanketoimijat koettavat sopeutua olemassa olevaan palvelujärjestelmään.

Avainryhmien tuottama tieto pohjautuu heidän kokemuksiinsa ja näkemyksiinsä kohteena olevasta toiminnasta. Tämän vuoksi avainryhmien näkökulmat ja painopistealueet voivat poiketa toisistaan. (Vartiainen 2007, 157.) Tutkimuksessamme asiakkaat arvioivat palveluja käyttäjän näkökulmasta, terveydenhuollon toimijat pääasiassa edustamansa toimintaympäristön (kunnallishallinto tai terveydenhuollon hallinto sekä perusterveydenhuolto) näkökulmasta. Hanketoimijat edustavat kehittämisen näkökulmaa.

Vartiainen $(2007,166)$ jakaa monitahoarvioinnin aineistot tunnuspiirteiden kautta neljään ryhmään: subjektiivinen aineisto, intersubjektiivinen aineisto, subjektiivinen ja intersubjektiivinen dokumentoitu aineisto sekä objektiivinen fakta. Tässä tutkimuksessa käytetyt aineistot ovat subjektiivisia, intersubjektiivisia sekä intersubjektiivisia dokumentoituja aineistoja. Aineistot voidaan pääosin luokitella subjektiivisiksi aineistoiksi, koska niiden perusominaisuuksia ovat avainryhmien ja sitä kautta yksilöiden väliset mielipiteet ja kokemukset, jotka eroavat avainryhmien välillä toisistaan. Intersubjektiivisuuden piirtei- tä löytyy myös, koska avainryhmät ja yksilöt jakavat esitettyjä mielipiteitä, asenteita ja kokemuksia keskenään joko osaksi tai kokonaan. Subjektiivinen aineisto tuottaa monipuolista informaatiota ja potentiaalista ristiriitaisuutta. Intersubjektiivinen aineisto tuottaa yhteisymmärrystä henkilöiden tai avainryhmien välillä. Kootun aineiston tiedonanalyyttinen yhdistäminen tekee arvioinnista monitahoisen ja tuottaa kokonaisvaltaisen käsityksen työttömien terveydenhuollon kehittämisestä.

Monitahoarvioinnissa tutkimustulosten luotettavuus ja hyödynnettävyys paranevat, kun arviointiprosessissa sovelletaan eri tutkimusmenetelmiä. Monitahoarvioinnin kontekstisidonnaisuus tarkoittaa sitä, että arviointiprosessissa toisiinsa suhteutetaan yleinen ja erityinen. Yleinen viittaa tieteellisiin ja teoreettisiin tutkimusperiaatteisiin ja erityinen puolestaan tutkittavan ilmiön yksilöllisiin ja paikallisiin ominaisuuksiin. Tarkoituksena on siis soveltaa yleisiä tieteellisiä periaatteita erityiseen ilmiöön siten, että voidaan puhua ilmiön kontekstisidonnaisesta analyysista. (Vartiainen 2007.)

\section{Monitahoarvioinnin aineistot ja menetelmät}

Tutkimusaineisto kerättiin arviointiprosessin aikana vuosina 2015-2018. Tutkimuksen aineisto koostuu viidestä osasta ja eri näkökulmista. Näkökulmat ja aineisto on eritelty taulukossa 1.

Asiakasnäkökulmaan haastateltujen asiakkaiden (n=20) ikä oli 20-61 vuotta. Haastatelluista miehiä oli kahdeksan, loput 12 olivat naisia. Yksinasuvia oli 11, avio- tai avoliitossa olevia oli kuusi, kaksi haastatelluista asui muun perheen kanssa ja yhden henkilön taustasta ei ollut tietoa. Haastateltavat olivat hankkeen asiakkaita, jotka lupautuivat haastatteluun vapaaehtoisesti sekä antoivat kirjallisen suostumuksen haastattelun nauhoittamiseen ja tutkimuskäyttöön. Asiakasaineisto analysoitiin sisällönanalyysillä induktiivisesti koodaamalla (Taulukko 2). Analyysissä käytettiin 
Taulukko 1. Monitahoarvioinnin näkökulmat ja materiaalit

\begin{tabular}{|c|c|c|}
\hline Näkökulma & Materiaali & Teemat/aineiston määrä \\
\hline Asiakasnäkökulma & $\begin{array}{l}\text { Asiakashaastattelut }(n=20) \\
\text { Itsearviointikoosteet }(n=5)\end{array}$ & $\begin{array}{l}\text { Asiakashaastattelut (n. } 30 \text { min/haastattelu) } \\
\text { Teemat: terveystarpeet ja palvelujen } \\
\text { kehittämistarpeet, viranomaistoiminta, } \\
\text { mahdolliset kuntoutuskokemukset } \\
\text { Itsearviointikoosteet (n. } 4 \text { liuskaa) } \\
\text { Teemat: Mitä tuloksia ja vaikutuksia toiminnalla } \\
\text { on saatu aikaiseksi? Kehittämistarpeet jatkoa } \\
\text { ajatellen? }\end{array}$ \\
\hline Viranomaisnäkökulma & $\begin{array}{l}\text { Viranomaishaastattelut } \\
\text { terveydenhuollon ja TE-hallinnon } \\
\text { henkilöstölle vuosina } 2015 \text { ja } \\
2017(n=31)\end{array}$ & $\begin{array}{l}\text { Viranomaishaastattelut ( } 40 \mathrm{~min} / \text { haastattelu) } \\
\text { Teemat: työttömän hoito- ja palveluprosessi, } \\
\text { yhteistyö, kehittämistarpeet, kehittämisen kuvaus } \\
\text { n. } 5 \text { liuskaa }\end{array}$ \\
\hline $\begin{array}{l}\text { Hanketoimijoiden } \\
\text { näkökulma }\end{array}$ & $\begin{array}{l}\text { Itsearviointikoosteet }(n=5) \\
\text { Välitehtävä }\end{array}$ & $\begin{array}{l}\text { Itsearviointikoosteet: Mitä tuloksia ja vaikutuksia } \\
\text { toiminnalla on saatu aikaiseksi? } \\
\text { Välitehtävä: Kehittämistarpeet jatkoa ajatellen? } \\
\text { (n. } 4 \text { liuskaa) }\end{array}$ \\
\hline Päättäjien näkökulma & $\begin{array}{l}\text { Hankkeen ohjausryhmän } \\
\text { pöytäkirjat }(n=6) \\
\text { Itsearviointikoosteet }(n=5)\end{array}$ & Maininta kuudessa pöytäkirjassa n. 6 riviä \\
\hline Yhteistyönäkökulma & $\begin{array}{l}\text { Kehittävän vaikuttavuusarvioinnin } \\
\text { työpajat, Rauma, Turku, Salo }(n=6)\end{array}$ & $\begin{array}{l}\text { Fläppitaulut jokaisessa työpajassa, yht. } 18 \text { fläppiä } \\
\text { ja yhteenvedot } 18 \text { liuskaa }\end{array}$ \\
\hline
\end{tabular}

Taulukko 2. Asiakashaastattelujen ala, ylä- ja pääluokat, esimerkki

\begin{tabular}{|c|c|c|}
\hline Alaluokka & Yläluokka & Pääluokka \\
\hline Aikuispsykiatria & \multirow{9}{*}{$\begin{array}{l}\text { Terveydenhuollon eri } \\
\text { palvelujen käyttäminen }\end{array}$} & \multirow{15}{*}{$\begin{array}{l}\text { Kokemukset ja } \\
\text { kehittämisajatukset } \\
\text { terveydenhuollosta }\end{array}$} \\
\hline Erikoissairaanhoito & & \\
\hline Fysioterapia & & \\
\hline Hammaslääkäri & & \\
\hline Mielenterveyspalvelut & & \\
\hline Psykologi & & \\
\hline Työttömien terveystarkastus & & \\
\hline Kuntoutus & & \\
\hline Terveyskeskuspalvelut & & \\
\hline Ajanvaraus & \multirow{6}{*}{$\begin{array}{l}\text { Kehittämisajatukset } \\
\text { terveydenhuoltoon }\end{array}$} & \\
\hline Asiointi saman henkilön kanssa & & \\
\hline Pirstaleiset palvelut & & \\
\hline Samanarvoinen kohtelu & & \\
\hline Palvelun räätälöinti & & \\
\hline Tiedonkulun parantaminen & & \\
\hline
\end{tabular}


Atlas.ti-ohjelmistoa, jossa aineisto on kokonaisuudessaan dokumentoituna.

Viranomaisnäkökulmaan varten haastateltiin 31 viranomaista. Heidät valittiin alueen keskeisistä toimijoista, jotka olivat mukana työttömien työ- ja toimintakyvyn tukemiseen liittyvässä työssä. Haastatellut saivat tietoa tutkimuksesta ja he antoivat kirjallisesti tietoon perustuvan suostumuksensa tutkimukseen. Haastatteluja tehtiin hankeen alku- ja loppuvaiheessa (2015 ja 2017). Lopuksi aineistot yhdistettiin kokonaisvaltaisen näkemyksen luomiseksi. Viranomaishaastattelut analysoitiin induktiivisesti teemoittelemalla. Teemoja olivat muun muassa yhteistyö TE-toimiston kanssa, palvelutarpeiden tunnistaminen, oma rooli työttömän työ- ja toimintakyvyn tukemisessa sekä työ- ja toimintakyvyn arvioinnin toteuttaminen. Toisessa vaiheessa samansisältöisiä teemoja yhdisteltiin ja osa teemojen nimistä vaihdettiin. Terveydenhuollon aineistoon jäi 18 teemaa ja TE-toimiston aineistoon 25 teemaa. Tämä tapahtui kahden tutkijan yhteistyönä käyttäen apuna Excell-taulukkoa. Aineisto on kokonaisuudessaan Atlas.ti-ohjelmistossa tallennettuna.

Hanketoimijoiden näkökulma koostui itsearvioinneista, jotka tehtiin viisi kertaa hankkeen aikana. Itsearviointikyselyjen tulokset purettiin yhdessä kaikkien hanketoimijoiden kesken ja niitä täydennettiin laadullisin arvioinnein.

Kehittävää vaikutusten arviointia tehtiin arviointityöpajoissa $(n=6)$ (Saari \& Kallio 2011; Patton 1997). Pajatyöskentelyssä käytettiin kehittämisprosessista koottua aineistoa. Kehittävässä vaikuttavuudenarvioinnissa tähdätään organisaation oppimiseen (Saari ym. 2008; Saari \& Kallio 2011). Kehittävällä arvioinnilla tarkoitetaan yleisesti arviointitiedon keräämistä ja hyödyntämistä arvioitavan kohteen kehittämistä varten. Intressinä on tällöin kehittäminen, muutos ja oppiminen. (Patton 2010; Anttila 2007.) Kehittävä vaikuttavuusarviointi pyrkii rakentamaan osallistujien kesken yhteisen käsityksen arvioitavana olevan toiminnan lähitulevaisuudesta (Saari \& Kallio 2011).

Päättäjien näkökulmaa edusti ohjausryhmä. Ohjausryhmän kokouksia oli kuusi. Ohjausryhmän kokouksien sisältö painottui hankkeen etenemisen arviointiin. Osassa kokouksista nousi esiin työttömien terveyspalveluiden kehittäminen.

Tarkastelua tehtiin mikro-, meso- ja makrotasolla. Mikrotaso käsittää yksilön lähimmän tarkastelunäkökulman (asiakashaastattelut). Mesotasoon liittyy laajempi vuorovaikutus toimintaympäristössä (hanketoimijat ja viranomaiset). Makrotaso tarkoittaa koko arvioinnin kohteena olevaa näkökulmaa (päättäjät). (Miller \& Wilson 1998.) Yhteistyönäkökulma korostuu kaikilla tarkastelutasoilla.

Tutkimukseen valittiin keskeiset toimijat, joita olivat asiakkaat, hanketoimijat, peruspalvelujen viranomaiset sekä ohjausryhmä (vrt. Miller \& Wilson 1998). Tavoitteena oli saada laaja näkökulma työttömien terveydenhuollon toimijoita (Saari \& Kallio 2011). Keskeisten toimijoiden kanssa pohdittiin myös, onko olemassa tutkimuksen näkökulmasta tärkeitä piileviä avainryhmiä. Sellaisia piileviä avainryhmiä, jotka olisivat relevantteja tutkimuksen kannalta, ei kuitenkaan löytynyt.

Monitahoarviointia sovellettiin työttömien terveyspalvelujen kehittämisen arviointiin kiinnittäen arviointiprosessissa huomiota erityisesti taulukossa 3 esiteltyihin periaatteisiin, joita olivat avainryhmien rooli, aineiston monipuolisuus, arviointikriteeristön muodostaminen ja arvolausekkeet.

Arviointikriteerit muodostettiin kontekstija sisältötekijät huomioiden. Konteksti ohjaa sisältöä korostavien kriteerien muodostamiseen. Koska kyse on työttömien terveydenhuollon kehittämisestä, muodostui kriteeristö käytännönläheisesti. Pääkriteerit ovat työttömien terveydenhuollon kehittäminen sekä työttömien terveyspalvelujen toteutuminen. Alakriteerit ovat työttömien terveyspalvelujen yhteistyöverkosto sekä työttömien terveyspalveluiden arviointi. Kriteerien avulla arvioidaan 
Taulukko 3. Monitahoarvioinnin periaatteet

\begin{tabular}{|l|l|l|}
\hline Periaate & Ominaisuus & Tarkoitus \\
\hline Avainryhmien rooli & $\begin{array}{l}\text { Arvioinnin pääasiallinen } \\
\text { informaatiolähde }\end{array}$ & $\begin{array}{l}\text { Selvittää työttömien } \\
\text { terveyspalveluiden kehittämisen } \\
\text { näkökulmia }\end{array}$ \\
\hline Aineiston monipuolisuus & $\begin{array}{l}\text { Kerätään eri avainryhmiltä } \\
\text { monipuolista ja koherenttia tietoa }\end{array}$ & $\begin{array}{l}\text { Tuottaa kokonaisvaltainen näkemys } \\
\text { työttömien terveyspalveluiden } \\
\text { kehittämisestä ja siihen } \\
\text { vaikuttavista tekijöistä }\end{array}$ \\
\hline $\begin{array}{l}\text { Arviointikriteeristön } \\
\text { muodostaminen }\end{array}$ & $\begin{array}{l}\text { Muodostetaan työttömien } \\
\text { terveyspalveluiden vaikutusten ja } \\
\text { kehittämisprosessien avulla }\end{array}$ & $\begin{array}{l}\text { Kriteeristön avulla aineistosta } \\
\text { poimitaan oleellinen ja eri } \\
\text { näkökulmat yhdistetään }\end{array}$ \\
\hline Arvolausekkeet & $\begin{array}{l}\text { Konkretisoivat tulokset selkeään } \\
\text { muotoon ja arvottavat toimintaa }\end{array}$ & \begin{tabular}{l} 
Konkretisoivat arviointitulokset \\
\hline
\end{tabular} \\
\hline
\end{tabular}

työttömien terveydenhuollon toimivuutta. Arvioinnissa analysoidaan työttömien terveyspalvelujen kehittämistä ja kehittämiskäytänteitä.

\section{Tulokset}

\section{Avainryhmänä asiakkaat}

Asiakkaat näkivät terveydenhuollon kehittämistarpeena helpomman hoitoon pääsyn ja tasa-arvoisen kohtelun. Joillakin haastatelluilla oli kokemus, että työttömät eivät saa tasa-arvoista kohtelua terveydenhuollossa. Puhelinkontaktissa oman asian kertominen saattoi olla vaikeaa ja asiakkaat toivoivat, että asian pääsisi kertomaan kasvotusten. Kielteisenä asiana asiakkaat näkivät henkilökunnan vaihtumisen, koska henkilökunnan vaihtuessa oman asian kertominen ja luottamuksen rakentaminen kyseiseen henkilöön piti aloittaa alusta.

Haastateltavista 11 oli käynyt terveystarkastuksessa. Kokemukset terveystarkastuksesta olivat pääosin myönteisiä. Erään asiakkaan kohdalla työkokeilu oli käynnistynyt terveystarkastuksen kautta:

Oli viime kesänä tässä terveyskeskuksessa kerran, että siitä laitettiin sillon Kelan just tää, työkykyarviointi et sielt tuli eilen just päätös et mä pääsen sinne työkokeiluun, ni se oli just sen työttömien terveyspalvelun kautta pääsi sinne. (mies, 53)

Mut en olis ikinä, ei olis tullu mentyy ite jos ei ois sitä työvoimatoimiston kautta laittaneet mut sairaanhoitajalle ja sitä kautta lääkärille. Olen hirveen tyytyväinen siihen. (nainen, 57)

Asiakkaat pitivät tärkeänä myös työkyvyn arviointia, palveluun ohjausta ja palvelutarpeen tunnistamista. Kaikilla työttömillä ei ollut tietoa oikeudesta hakeutua terveystarkastukseen tai kunnan velvollisuudesta järjestää palvelu. Muutama ei tunnistanut tarvetta terveystarkastukseen:

Ei ole ollu, siitä mä oisin tietysti kiinnostunu, jos semmonen olis. (mies, 52)

Ilmeisesti olis saanut semmose ajan, jos olis kokenu tarvitsevansa, mutta mä en käyttäny sitä mahollisuutta, oliko nyt kesän aikana, tarjottiin tämmöstä. (mies, 28)

No kyl mä voisin, toi olis aika hyvä toi, et jos joku tarkastais et onks mä edes työkuntoinen enää. Sitä ei oo kukaan testannu. (nainen, 55) 
Asiakkaat toivoivat viranomaisten välisen yhteistyön kehittämistä, koska samojen asioiden kertominen viranomaiselta toiselle oli turhauttavaa. He toivoivat myös TE-toimiston yhteydenottoa ja kasvokkain saatavaa palvelua:

No lähinnä ehkä tiedonkulkua eri viranomaistahojen välillä mun mielestä pystyis vielä kehittämään, et suurin piirtein samat tiedot olis sekä Kansaneläkelaitoksella kun noin eläkeyhtiölläki. Mut mun nähdäkseni ne kyllä sais olla työvoimaviranomasella, ja samoten, esimerkiks nyt Party-hankkeessa, jos tämän pariin vielä tulen, et hippasen ehkä alkaa jo kyllästyttää ko joka intressille saat ne erikseen selvittää. (mies, 58)

\section{Avainryhmänä hanketoimijat}

Itsearvioinnin ( $\mathrm{n}=5)$ tulokset on koottu hanketoimijoiden subjektiivisista, intersubjektiivisista ja dokumentoiduista intersubjektiivisista aineistoista. Arvioinnin kohteina olivat toiminta, vaikutukset, kehittämistä edesauttaneet ja haitanneet tekijät sekä toimintamallien rakentaminen.

Hanketoimijat pitivät asiakkaiden työ- ja toimintakyvyn selvittämistä monipuolisesti erityisen tärkeänä. He kokivat Kykyviisari-itsearviointimenetelmän (2019) pääosin hyvänä työkaluna. Asiakkaille oli löydetty jatkopolkuja työhön ja koulutukseen hanketyön ansioista. Heille oli järjestetty muun muassa kuntoutusedun kautta tuettuja opintoja. Itsearviointiin osallistuneet kokivat, että pitkäaikaistyöttömien palvelut olivat parantuneet ja erilaisista toiminnoista (keskeisimpinä ryhmätoiminnot) oli saatu paljon hyviä, jatkossa levitettäviä toimintamalleja. Asiakkaita oli saatu aktivoitua kuntouttavaan työtoimintaan ja he olivat pääsääntöisesti kokeneet sen mielekkääksi toiminnaksi.

Myös joidenkin asiakkaiden terveydentilan selvittelyt (lääkäri- ja asiantuntijalausunnot) olivat johtaneet asiakkaan tilanteen paranemiseen. Hanketoimijat kokivat tiedon asiakkai- den terveydentilasta ja siihen liittyvistä seikoista, kuten vaikutuksesta työkykyyn ja työllistymismahdollisuuksiin, erittäin hyödyllisenä.

Jotkut hankkeen asiakkaista olivat työllistyneet palkkatuen turvin. Hanketoimijat näkivät myönteisenä sen, että asiakkaita oli saatu aktivoitua. Asiakkaat olivat saaneet yksilöllistä palvelua elämäntilanteeseen sekä tarvitsemaansa tukea elämänhallintaan, talousneuvontaan ja henkilökohtaiseen työllistymisohjaukseen. Esimerkiksi pienryhmät olivat vahvistaneet asiakkaiden sosiaalista osallistumista ja edesauttaneet asiakkaiden ohjaamista kunkin tilanteeseen sopiviin tukityöpaikkoihin.

Yhdellä paikkakunnalla hanketoimijat kokivat haasteellisena kohderyhmän rajauksen 1000 päivää työmarkkinatukea saaneisiin henkilöihin. Tämä ryhmä oli ollut työttömänä kauan ja heidän kohdallaan erilaisia terveydentilan selvityksiä on tehty vuosien varrella. Hanketoimijat kokivat, että myös nuoret tulisi saada mukaan tällaisen palveluun. Heidän mielestään työikäisten palvelut tulisi suunnitella tasavertaisesti huolimatta siitä, onko pitkäaikaistyötön tai ei.

Hanketoimijat kokivat, että pitkäaikaistyöttömien polku kohti työelämää oli saatu toimivammaksi hanketoiminnan myötä. Eri tehtävissä toimivat työntekijät ja asiantuntijat oli saatu keskustelemaan keskenään ja tietoisiksi toistensa toiminnasta, mikä oli parantanut yhteistyötä työttömien palveluketjussa. Myös erilaisten toimintamallien juurruttaminen eteni yhteistyön tiivistyessä. Hanketoimijat näkivät tietämättömyyden toisten toiminnasta, toiminnan hajanaisuuden sekä kuntapäättäjien suhtautumisen esteinä työttömien terveyspalveluiden kehittämiselle. Lisäksi he kaipasivat työttömille koordinaattoreita työkyvyn ja terveyden edistämiseen.

Hanketoimijat kokivat, että myönteiset arviot asiakkaiden osallisuudesta lisääntyivät ja asiakkaiden työelämätaidot paranivat hankkeen aikana. Samoin yhteistyö terveydenhuollon toimijoiden, TE-toimiston, Kelan ja paikal- 
listen TYP-toimijoiden kesken kehittyi hankkeen aikana. Hanketoimijat kokivat hankkeen lisänneen heidän ja muiden toimijoiden kykyä verkostoitua ja kehittää yhteisiä ratkaisuja. Lisäksi hankkeen koulutukset lisäsivät terveydenhuollon toimijoiden osaamista.

Hankkeen aikana syntyi useita konkreettisia hyviä käytäntöjä. Hyvät käytännöt liittyivät kokonaisvaltaisiin toimintamalleihin, joilla oli vaikutusta eri tahojen tiiviiseen ja laajaan yhteistyöhön. Tiivis yhteistyö näkyi muun muassa sujuvana asiakkaiden ohjautumisena terveyspalveluihin. Lisäksi esimerkiksi ryhmätoiminnot, sosiaalisen kuntoutuksen sekä työja toimintakyvyn arvioinnin ja ylläpidon toimintamallit jäivät elämään hanketoiminnan jälkeen. Myös asiakasosallisuutta kehitettiin monin tavoin ja uudeksi toimintatavaksi useammalle paikkakunnalle tulivat säännöllisesti kokoontuvat asiakasraadit. Asiakasraadit koostuivat hankkeessa mukana olevista asiakkaista, jotka toimivat työttömien omia kokemuksia esiintuovina kokemusasiantuntijoina.

\section{Avainryhmänä viranomaiset}

Viranomaiset korostivat, miten tärkeää on tehdä kokonaisvaltainen arvio, joka sisältää myös asiakkaan psykososiaalisen kokonaisuuden ja siihen vaikuttavien tekijöiden arvioinnin. He nostivat myös esille eri viranomaisten tietorekisterien yhteiskäytön mahdollistamisen. Esille nousi myös tarve vähentää byrokratiaa terveydenhuollossa. Haastateltujen mukaan terveydenhuolto vaikuttaa asiakkaan näkökulmasta monimutkaiselta ja palvelujärjestelmää pitäisi yksinkertaistaa. Tähän ratkaisuna viranomaiset näkivät muun muassa rinnalla kulkemisen tai palveluohjauksen hyödyntämisen, työ- ja toimintakyvyn arvioinnin, asiantuntijoiden roolien selkeyttämisen sekä erilaisten luotettavien mittareiden käytön. Viranomaiset näkivät tarpeelliseksi asiakkaiden ongelmiin puuttumiseen välittömästi, kun huoli asiakkaan tilanteesta herää. Erityisen tärkeänä he pitivät työttömien terveydenhuollon kehittämistä jatkuvana toimintana.

TE-toimiston henkilöstö näki tärkeänä kehittämistarpeena terveydenhuollon kanssa tapahtuman, saumattoman ja asiakkaan asiaa eteenpäin vievän yhteistyön. Moniammatillinen yhteistyö nähtiin ensiarvoisen tärkeänä ja sitä korostettiin erityisesti TYP-toiminnassa. TE-toimiston henkilöstö koki myös, että työttömien terveydenhuoltoon nimetty asiakkaan palvelua koordinoiva terveydenhoitaja ja työttömien asioihin perehtynyt lääkäri olisivat tärkeitä yhteistyökumppaneita. He kokivat myös, että asiakasyhteistyöryhmä-tyyppinen toiminta on toimivaa ja asiakkaan kokonaisvaltaista hoitoa palvelevaa.

Työttömien terveydenhuollon kehittämiseen tarvitaan haastateltujen mukaan hyvää kehittämisasennetta sekä toimivia yhteistyökäytänteitä. Selkeät, yhteiset toimintamallit tukevat palvelun toteuttamista. Viranomaisten väliseen tietojen vaihtoon haastatellut kaipasivat toimivuutta esimerkiksi toimivien lähetepalaute-käytäntöjen myötä. Viranomaiset näkivät, että yhteisen ymmärryksen löytyminen eri viranomaisten kesken on tärkeää. Myös riittävien resurssien turvaaminen nousi esille viranomaishaastatteluissa. Hankealueella viranomaiset kokivat, että terveyspalvelut eivät olleet välttämättä riittäviä työttömille, sillä joillakin paikkakunnilla ei esimerkiksi toteutettu työttömien terveystarkastuksia säännöllisesti tai palvelut olivat hajallaan.

\section{Avainryhmänä päättäjät}

Päättäjien keskustelussa nousi esiin työttömien palveluiden painottuminen ryhmätoimintaan. Yksilöasiakkuuden koettiin kulkevan rinnalla. Esille nostettiin työttömien palveluiden kehittäminen negaatioiden kautta, minkä johdosta tulevaisuudessa kehittämistyöhön haluttiin positiivista asennetta. Päättäjät kokivat, että työttömien terveyspalveluihin tarvitaan käytäntöjen mallintamista ja jakamista. 
Ohjausryhmän jäsenet keskustelivat TEhallinnon roolista, ja he kaipasivat sinne varhaista puuttumista. Terveydenhuollon osalta pohdinnassa olivat lisätoimet terveystarkastuksen lisäksi. Keskusteluissa esille nousi muun muassa kuntoutukseen ohjaus ja lääkärien osaamisen kehittäminen. Päättäjät pohtivat myös, mitä sote- ja maakuntauudistus tuovat mukanaan. Keskustelussa epäkohtana nostettiin esille se, että työttömien terveyspalvelut näyttävät hajanaisilta.

Ohjausryhmän mukaan työttömien terveydenhuolto vaatii kehittämistä. Työttömän terveystarkastuksesta ei useinkaan synny varsinaista kuntoutussuunnitelmaa (poikkeuksena TYP-työ). Lisäksi kuntoutuksen eteneminen edellyttää sisällöltään asianmukaista lääkärintodistusta. Sisällöltään liian kapeat lääkärintodistukset eivät olleet edistäneet kuntoutustuen tai työkyvyttömyyseläkkeen saamista.

\section{Kehittävä vaikuttavuusarviointi}

Kehittävällä vaikuttavuusarvioinnilla tehtiin suunnitelmaa hanketoiminnan juurruttamiseksi, pohdittiin ideoiden käytäntöön viemistä sekä kokeilujen edelleen kehittämistä ja levittämistä. Työskentely tapahtui hanketoimijoiden ryhmätöinä, jossa Työterveyslaitoksen asiantuntijat toimivat fasilitaattoreina. Hankkeessa kehittävä vaikuttavuusarviointi toteutettiin kolmella paikkakunnalla kahden työpajan prosessina. Työpajat rakentuivat edellä kuvattujen tulosten pohjalle. Keskeisimpinä juurrutettavina asioina ja konkreettisina toimenpiteinä osallistujat nostivat esille sosiaalisen kuntoutuksen ryhmien jatkamisen, rinnalla kulkemisen ja yksilöllisen ohjauksen, henkilöresurssien lisäämisen asiakastyöhön, keskeisten moniammatillisten toimijoiden suunnitelmalliset yhteistyöpalaverit sekä palvelujen keskittämisen.

Osallistujat nostivat esille terveydenhuollon hyvän osaamisen ja monialaisen yhteistyön näkökulman. He näkivät myös asiakkaan rinnalla kulkemisen tärkeänä. Esille nousi huoli resursseista yhteistyön tekemisen edellytyk- senä. TE-toimiston näkökulmasta työllistäminen on ensisijainen tavoite, mikä voi olla haaste toimintakyvyn tukemisessa. Osallistujat pitivät liian vähäisiä valtuuksia ja byrokratiaa esteenä yhteistyön tekemiselle. Henkilöstö toivoi eri viranomaisten yhteisiä palavereita, sillä olemassaolevassa yhteistyössä koettiin puutteita. He pitivät hyvää yhteishenkeä vahvuutena ja nostivat esiin riittävän budjetin varmistaminen, jotta luodut toimivat toimintamallit voitaisiin juurruttaa. Henkilöstö toivoi moniammatillisuutta, vuoropuhelua ja hyvää keskusteluyhteyttä. Tulevaisuuden kehittämistoiveena oli yhteisen asiakastietojärjestelmän luonti sekä sellaiset muutokset lainsäädäntöön, jotka tukisivat yhteistyön kehittämistä esimerkiksi tuloloukkujen osalta. Osallistujat näkivät sote-uudistuksen mahdollisuutena kehittää uusia ja vahvistaa nykyisiä toimintatapoja. Konkreettinen idea oli toimintojen siirtäminen saman katon alle, jolloin fyysinen läheisyys helpottaisi yhteistyötä.

Työpajoihin osallistuneet näkivät sosiaalisen kuntoutuksen ja terveydenhuollon välisen yhteistyön toimivana ja hyvänä. Yhteistyön toimimisen edellytyksinä nousi esille rohkeus ja ennakkoluulottomuus toimia asiakastarve edellä. Myös motivaatio ja joustavuus olivat keskeisiä asioita kehittämistyössä. Osallistujien mukaan toimijoiden mielipiteitä pitää tuoda esille ja niitä pitää kysyä. Estävinä tekijöinä nousi esille kiire, resurssipula ja henkilökunnan vaihtuminen. Yhteistyön kehittymisen näkökulmasta osallistujat näkivät uuden työkulttuurin luomisen tärkeänä. Samoin tärkeäksi koettiin jatkuva tiedonkulku ja verkoston toimiminen. Osallistujat halusivat arvostaa moniammatillista työtä sekä nähdä sen vahvuutena. Myös säännöllisiä yhteistyöverkoston kokoontumisia kaivattiin. Riittävien resurssien turvaaminen budjetissa oli keskeinen asia. Myös palvelujen keskittäminen saman katon alle nousi tärkeään rooliin.

Osallistujien mukaan Party-hankkeessa oli kehitetty uudenlaisia tapoja työttömien palveluprosessiin ja terveydenhuoltoon. Uusia ideoita olivat muun muassa ryhmätoimintamalli, 
asiakasraati, monialaisen verkoston malli, pienryhmätoiminta, kuntoutuskoordinaatio, asiakasprosessin kokonaisvaltainen vastuutus sekä asiakaskuntaan perehtynyt lääkäri.

Työpajaan osallistuneet kokoivat työttömien terveydenhuollon muuttuneen hanketoiminnan myötä aiempaa koordinoidummaksi. Varhaisemman vaiheen yhteistyö painottui hankkeen myötä enemmän. Myös hoitovastuut ovat selkeämmät ja asiakkaan palveluprosessi selkeytyneempi. Kehittämistarpeena he näkivät edelleen osaamisen vahvemman yhdistämisen. Monialaisesta työstä pitäisi päästä kollektiiviseen asiantuntijuuteen, jotta asiakkaan etu palvelussa toteutuisi paremmin. Lisäksi tarvitaan uudenlaista johtamistapaa.

Työttömien palvelussa on tärkeää yksilöllisyys, sillä asiakkailla on hyvin erilaisia lähtökohtia ja palvelutarpeita. Hanketoimijat olivat tunnistaneet, että esimerkiksi massainfot olivat toimimattomia. Tarvitaan intensiivistä palveluohjausta, koska asiakasta ei voi jättää vastuuseen oman prosessinsa etenemisestä ja omien tietojensa toimittamisesta eri toimijoille. Tämä vaatii resursointia ja palvelujen sijoitusta saman katon alle.

\section{Tulosten yhteenveto ja pohdinta}

Tämän tutkimuksen tavoitteena oli arvioida työttömien terveydenhuollon kehittämistä eri toimijoiden näkökulmista monitahoarvioinnin viitekehyksessä. Arvioinnin tulokset rakennettiin näkökulmittain, jotka yhdistettiin. Oheiseen taulukkoon on koottu yhteenveto edellä esitellyistä tuloksista (Taulukko 4).

Kaikissa näkökulmissa painottui tarve yhteistyön tiivistämiseen ja toimintamallien rakentamiseen. Viranomaiset ja hanketoimijat kaipasivat kokonaisvaltaista palvelua ja tiedon koordinointia. Lisäksi he toivoivat asiakkaalle keskeisempää roolia.

Asiakasnäkökulmassa korostui tarve joustavaan ja helppoon hoitoon pääsyyn sekä tasaarvoisiin terveyspalveluihin. Asiakkaat pitivät tärkeänä asiakkaat kokonaisvaltaisesti yksi- löinä huomioivaa henkilökuntaa. Myös viranomaiset korostivat kokonaisvaltaisen näkemyksen luomista asiakkaan tilanteesta. Esille nousivat tietojärjestelmien kehittämisen tärkeys ja varhaisempi puuttuminen asiakkaan ongelmiin. Lähes kaikissa näkökulmissa korostui kehittämistarpeena toimivampi yhteistyö, yksilöllinen ohjaus ja rinnalla kulkeminen sekä kokonaisvaltainen palvelun koordinointi.

Hanketoimijoiden tuloksissa keskeisenä asiana nousi esiin yhteistyön lisääminen sekä kuntapäättäjien tehokkaampi tiedottaminen asioista. Päättäjien mukaan tarvitaan selkeämpiä toimintaohjeita ja mallintamista sekä osaamisen lisäämistä erityisesti perusterveydenhuollon lääkäreiden keskuudessa. Yhteistyönäkökulmasta riittävien henkilö- ja raharesurssien turvaaminen on keskiössä, samoin tärkeää on moniammatillisuus, yhteistyö ja uusien toimintatapojen oppiminen, jotta palvelu olisi toimivaa.

Subjektiiviset aineistot erosivat avainryhmien välillä jonkin verran toisistaan. Asiakasnäkökulmasta esille nousivat henkilökunnan vaihtumisen kielteiset kokemukset, mutta ne eivät olleet esillä viranomaisten tai hanketoimijoiden näkemyksissä. Resursseihin liittyvät asiat olivat pelkästään viranomaisten jakamia käsityksiä. Tietojärjestelmiin ja byrokratiaan liittyvät tulokset painottuivat viranomaisten, hanketoimijoiden ja päättäjien näkemyksissä, mutta ne eivät tulleet esille asiakkaiden näkemyksissä. Myöskään terveydenhuoltohenkilöstön osaamiseen liittyvät tekijät eivät nousseet esille asiakasnäkemyksissä, toisin kuin viranomaisten ja päättäjien näkemyksissä.

Intersubjektiivisissa aineistoissa eri toimijat jakoivat mielipiteitä yhdessä. Esimerkiksi eri viranomaisten tietojen vaihtoon liittyvät asiat sekä yhteistyön lisääminen olivat kehittämistarpeena yhteisesti jaettu näkemys kaikilla avainryhmillä. Myös kokonaisvaltaisen näkemyksen ja arvioinnin tarve olivat yhteisiä näkökulmia asiakastyössä sekä asiakkaiden kokemana. Tiedon ja asiakasprosessin koordinointi tuli esille kaikissa muissa avainryhmissä asiakasnäkökulmaa lukuun ottamatta. 
Taulukko 4. Yhteenveto tuloksista

\begin{tabular}{|c|c|c|}
\hline Näkökulma & Tulos & Tulkinta \\
\hline Asiakas & $\begin{array}{l}\text { - Tasa-arvoinen kohtelu ei välttämättä toteudu } \\
\text { - Henkilökunta on vaihtuvaa } \\
\text { - Hoitoon pääsy ei ole helppoa } \\
\text { - Palveluohjaus terveystarkastuksiin ei } \\
\text { välttämättä toimi } \\
\text { - Tiedonkulku eri viranomaisten kesken ei } \\
\text { välttämättä toimi } \\
\text { - Tarve kokonaisvaltaisen terveydentilan } \\
\text { selvittämiseen } \\
\text { - Yksilöllinen kohtaaminen } \\
\text { - Terveystarkastus on toiminut väylänä } \\
\text { työkokeiluun } \\
\text { - Terveyspalvelut ovat tehostuneet hankkeen } \\
\text { aikana }\end{array}$ & $\begin{array}{l}\text { - Samanarvoinen kohtelu ja tasalaatuiset } \\
\text { palvelut kaikille työikäisille } \\
\text { - Pysyvä omalääkäri/-hoitaja } \\
\text { - Helppo ajanvarausjärjestelmä } \\
\text { - Tiedotus terveystarkastuksista ja } \\
\text { ohjaaminen palveluun eri tahoilta } \\
\text { - Tietojärjestelmien sekä lähete- } \\
\text { palaute-käytäntöjen sopiminen ja } \\
\text { toimintamallien luominen } \\
\text { - Moniammatillinen yhteistyö } \\
\text { terveydenhuollossa }\end{array}$ \\
\hline Viranomaiset & $\begin{array}{l}\text { - Kokonaisvaltaisen arvion tekeminen ei } \\
\text { välttämättä onnistu } \\
\text { - Virananomaisten asiakasrekisterien } \\
\text { yhteiskäyttö ei toimi } \\
\text { - Monimutkainen palvelujärjestelmä } \\
\text { - Varhaisempi puuttuminen asiakkaiden } \\
\text { ongelmiin on tarpeellista } \\
\text { - Tarvitaan osaava lääkäri ja terveydenhoitaja } \\
\text { - Moniammatillinen toiminta on koettu hyväksi } \\
\text { - Hyviä, toimivia käytäntöjä on jo olemassa }\end{array}$ & $\begin{array}{l}\text { - Luotettavien mittareiden käyttö } \\
\text { arvioinnissa } \\
\text { - Case managereiden käyttäminen } \\
\text { - Roolien selkeyttäminen } \\
\text { - Moniammatillisen yhteistyön } \\
\text { tekeminen } \\
\text { - Asiakasyhteistyöryhmä-tyyppisen } \\
\text { toiminnan varmistaminen } \\
\text { - Työttömien asioihin perehtynyt } \\
\text { henkilökunta ja palvelun koordinointi } \\
\text { terveydenhuollossa }\end{array}$ \\
\hline Hanketoimija & $\begin{array}{l}\text { - Tietämättömyyttä toisten toiminnasta } \\
\text { - Toimijoiden hajanaisuus hankaloittaa työtä } \\
\text { - Kuntapäättäjien suhtautuminen hanketyöhön } \\
\text { ei ole välttämättä positiivista } \\
\text { - Verkostomainen työskentely ja yhteistyö on } \\
\text { lisääntynyt } \\
\text { - Asiakkaiden osallisuus on lisääntynyt, } \\
\text { asiakasraadit käytössä } \\
\text { - Asiakkaiden tilanteet ovat edenneet } \\
\text { hanketoiminnan ansioista } \\
\text { - Hyviä käytäntöjä on syntynyt } \\
\text { - Hankkeen koulutustyö on koettu hyödyllisenä }\end{array}$ & $\begin{array}{l}\text { - Yhteistyön tiivistäminen } \\
\text { - Palvelujen keskittäminen } \\
\text { - Kuntapäättäjien tiedottaminen ja } \\
\text { yhteistyö } \\
\text { - Hyvien käytäntöjen juurruttaminen } \\
\text { - Asiakkaiden rinnalla kulkemisen } \\
\text { huomioiminen } \\
\text { - Asiakkaiden osallistaminen } \\
\text { - Moniammatillisten koulutusten } \\
\text { toteuttaminen }\end{array}$ \\
\hline Päättäjät & $\begin{array}{l}\text { - Käytännön toimintaohjeita ei ole riittävästi } \\
\text { - Asiakkaiden ongelmiin puututaan liian } \\
\text { myöhään } \\
\text { - Turhia lääkärinlausuntoja, joilla ei } \\
\text { läpimenomahdollisuuksia eläke- tai } \\
\text { kuntoutusjärjestelmässä } \\
\text { - Positiivinen ja innostava kehittämistyö } \\
\text { kannattaa }\end{array}$ & $\begin{array}{l}\text { - Toimintojen mallintaminen } \\
\text { - Varhainen puuttuminen asiakkaan } \\
\text { ongelmiin } \\
\text { - Osaamisen lisääminen mm. } \\
\text { lääkärilausuntojen kirjoittaminen } \\
\text { terveydenhuollossa } \\
\text { - Kehittämistyöhön positiivinen ote, } \\
\text { vahvuuksien hyväksikäyttö }\end{array}$ \\
\hline $\begin{array}{l}\text { Yhteistyö- } \\
\text { näkökulma }\end{array}$ & $\begin{array}{l}\text { - Resurssit eivät ole riittävät } \\
\text { - Byrokratia yhteistyön esteenä } \\
\text { - Yhteisiä palavereja liian vähän } \\
\text { - Moniammatillisuutta tarvitaan lisääa } \\
\text { - Palvelut ovat hajallaan } \\
\text { - Asiakasrekisterit eivät keskustele keskenään } \\
\text { - Terveydenhuollossa on hyvää osaamista } \\
\text { - Hyvä yhteishenki kehittämistyössä } \\
\text { - Moniammatillinen yhteistyö on vahvuus }\end{array}$ & $\begin{array}{l}\text { - Henkilö- ja raharesurssien turvaaminen } \\
\text { - Yhteistyötoimintatavoista sopiminen, } \\
\text { ennakkoluulottomuus, motivaatio } \\
\text { - Toimintatapojen muuttaminen ja } \\
\text { uusien toimintamallien käyttäminen } \\
\text { palvelujärjestelmässä } \\
\text { - Yhteiset säännölliset foorumit } \\
\text { - Palvelujen keskittäminen } \\
\text { - Yhteisten tietojärjestelmien } \\
\text { kehittäminen }\end{array}$ \\
\hline
\end{tabular}


Työttömien terveyspalvelut ja niiden kehittäminen koettiin tärkeinä kaikissa avainryhmissä ja hanketoiminnan koettiin parantaneen yhteistyökäytänteitä, terveydenhuoltoon ohjaamista sekä jatkopolkuja.

\section{Johtopäätökset}

Aikaisemman tutkimuksen osalta tiedetään, että työvoimapolitiikan taloudelliset kannustimet ja sanktiot lisäävät työllistymistä jonkin verran, kuitenkin ainoastaan niiden ryhmien kohdalla, joilla on todellisia edellytyksiä työllistyä. Sen sijaan huono-osaisten ryhmien kohdalla toimenpiteiksi suositellaan ensin kuntouttavia toimia, koska ilman kuntoutusta taloudelliset kannustimet ja niin sanotut kovat toimenpiteet vaikuttavat kielteisesti sekä mielenterveyteen että myös työllistymiseen. (Malmberg-Heimonen 2005.) Olisi tärkeä huomioida työttömien yksilökohtaiset erot, jotta työttömien työ- ja toimintakyvyn sekä työllistymisen tukeminen olisi tehokasta. Myös tässä arviointitutkimuksessa asiakaslähtöisyys nousi tärkeänä tekijänä esille. Vaikka suosituksia työttömien terveydenhuollosta ja työkyvyn arvioinnista on tehty (esimerkiksi Vuokko ym. 2012), erityisesti lääkäreiden osaamisessa on suurta vaihtelua. Työttömien terveyspalvelut eivät ole riittävät, eikä heille ole tarjolla ehkäisevää terveydenhuoltoa siten kuin työssä oleville. Myös kuntoutustoimet ovat vähäisempiä työttömien kohdalla. Pitkään työttömänä olleille myös kynnys hakeutua hoitoon voi olla korkea (Kerätär \& Karjalainen 2010; Heponiemi ym. 2008; Åhs ym. 2006).

Työttömien terveyspalveluihin liittyvät kehittämistarpeet ovat olleet tiedossa jo pitkään, mutta kokoava arviointitieto puuttuu. Tulosten mukaan työttömien terveydenhuollossa tehtävä viranomaisyhteistyö edistää kokonaisvaltaista asiakastyötä (vrt. Lappalainen 2017a; 2017b). Työttömyyden pitkittyminen johtaa usein terveysongelmiin ja työttömäksi jääneet näyttävät olevan sairaampia kuin muu väestö (Heponiemi ym. 2008). Työttömyyteen liittyvät monimuotoistuneet terveydelliset on- gelmat vaativat moniammatillista verkostotyötä eri sidosryhmien välillä (Karjalainen ym. 2008). Suomen eduskuntaryhmät ovat sitoutuneet käynnistämään valtakunnallisen ohjelman, jolla edistetään työikäisten työkykyä. Tarve moninäkökulmaiselle palvelujärjestelmälle on ehdoton ja TE-palvelujen rinnalle tarvitaan terveydenhuollon palveluja (TEM, STM 2019). Selvityshenkilöt Oivo ja Kerätär (2018) ehdottavat, että käynnistetään työkykyohjelma, jonka tavoitteena olisi muun muassa työelämäosallisuuden lisääminen tunnistamalla palvelutarve riittävän varhain ja tehostamalla kuntoutuspalveluja. Prosessin koordinoija olisi työelämän ulkopuolella olevien osalta kunnan sosiaalityö. Lisäksi perustettaisiin työkykykeskus, jossa on riittävä eritystason osaaminen.

Yhteistyö vaatii tiivistämistä nykyisessä palvelujärjestelmässä. Moniammatillinen osaaminen työttömän terveyspalveluissa sekä terveystarkastusten että työkyvyn arvioinnin osalta ei toteudu riittävän tehokkaasti. Eritasoista osaamista olisi hyödyllistä yhdistää nykyistä paremmin. Myös monitieteistä tutkimusta, jossa arvioidaan vaikuttavuutta esimerkiksi panos-tuotos-lähtökohdista käsin, kannattaisi tehdä tulevaisuudessa, jotta palvelujen vaikuttavuus saataisiin esille. Hyviä alueellisia malleja, joita on otettu käyttöön, olisi hyödyllistä arvioida vaikuttavuuden näkökohdista käsin, jotta toimivat palvelut olisi helpompi ottaa käyttöön laajemmin myös kansallisesti. Toimintamalleja on luotu esimerkiksi OTEkärkihankkeissa: Keski-Suomen sairaanhoitopiirin Saumaton hoitoketju ja kuntoutuspolku työikäiselle -hankkeessa sekä Pirkanmaan ja Etelä-Pohjanmaan Toimintakykykeskus-hankkeessa (Mattila-Wiro \& Tiainen 2019). Lisäksi esimerkiksi Pohjois-Karjalassa on luotu yhteistyötä työ- ja toimintakyvyn arvioinnin osalta perusterveydenhuollon ja erikoissairaanhoidon välillä. Työikäisten terveydenhuoltoa kannattaisi katsoa palvelukokonaisuutena rakennettaessa mahdollista sosiaali- ja terveydenhuollon uudistamiskokonaisuutta, jotta tasa-arvoiset terveyspalvelut olisivat kaikkien 
työikäisten ulottuvissa. Palvelukokonaisuudessa olisi hyvä huomioida sekä työssä olevat että työttömät. Tässä uudistamisessa myös työterveyshuollon osaamisen varmistaminen olisi kannatettavaa, sillä siellä on erityisosaamista työn ja terveyden yhteensovittamisesta, työkyvyn arvioinnista ja kuntoutusmahdollisuuksista. Keskeisin tavoite on tasa-arvoisten terveyspalvelujen tuottaminen kaikille työikäisille henkilöille. Myös yksilöllinen kohtaaminen ja rinnalla kulkeminen sekä todellisten asiakastarpeiden, kuntoutustarpeiden sekä motivaation huomioiminen kokonaisvaltaisesti tukevat asiakasta kohti työllistymistä ja osallisuutta.

Tämä arviointitutkimus tuottaa osaltaan koottua tietoa ajankohtaisesta aiheesta työelämän kannalta. Arviointikriteerit muodostuivat työttömien terveyspalvelujen yhteistyöverkoston toimivuudesta ja työttömien terveyspalveluiden evaluoinnista. Arvioinnin pohjalta olemme muodostaneet seuraavat arvolausekkeet:

1. Työttömien terveyspalvelujen yhteistyöverkosto toimii satunnaisesti. Yhteistyön tiivistämistä ja pysyviä rakenteita tarvitaan. Palvelussa on oltava koordinaattori.

2. Asiakas tulee osallistaa oman terveyden, työkyvyn ja työllistymisen prosessin hallintaan.

3. Työttömien terveyspalveluja on kehitetty pitkälti hanketoimintana. Yhteistyöverkostojen pitää olla pysyviä, toimivia ja moniammatillisia.

\section{Kiitokset}

Kiitokset Työterveyslaitoksen erikoistutkija Hilkka Ylisassille tekstin kommentoinnista. Kiitämme myös Euroopan sosiaalirahastoa (ESR) tutkimuksen rahoituksesta.

\section{Kirjoittajat}

Kirsi Lappalainen, TtT, tuotepäällikkö, sähköposti: kirsi.lappalainen@ttl.fi

Hanna Hakulinen, TtM, kehittämispäällikkö, sähköposti: hanna.hakulinen@ttl.fi

\section{Kirjallisuus}

Anttila, P. (2007) Realistinen evaluaatio ja tuloksellinen kehittämistyö. Hamina: Akatiimi.

Brussige, M., Dragano, N. \& Mümkene, S. (2014) Health promotion for unemployed jobseekers: New developments in Germany. Health Policy 114 (2-3), 192-199. https://doi.org/10.1016/j.healthpol.2013.09.017

Böckerman P. \& Ilmakunnas P. (2008) Unemployment and self-assessed health: Evidence from panel Datapetri Health Economics. Health Economics 18 (2), 161-179.

https://doi.org/10.1002/hec.1361

Chetkow-Yanoov B. (1992) Social Work Practice. A Systems Approach. New York: The Haworth Press.

Connolly, T., Conlon, E. \& Deutch, S. (1980) Organizational effectiveness: A multiple-constituency approach. Academy of Management Review 5 (2), 211-217. https://doi.org/10.5465/amr.1980.4288727

Guba, E. G. \& Lincoln, Y. S. (1989) Fourth Generation Evaluation. Newbury Park: CA: Sage.

Hallituksen toimintasuunnitelma. (2019) Osallistava ja osaava Suomi - sosiaalisesti, taloudellisesti ja ekologisesti kestävä yhteiskunta. Helsinki: Valtioneuvosto.

Hammarström, A. \& Janlert, U. (2002) Early unemployment can contribute to adult health problems: Results from a longitudinal study of school leavers. Journal of Epidemiology Community 
Health 56 (8), 624-630.

https://doi.org/10.1136/jech.56.8.624

Heponiemi T., Wahlström M., Elovainio M., Sinervo

T., Aalto A-M., Keskimäki I. (2008) Katsaus työttömyyden ja terveyden välisiin yhteyksiin. [online]. <URL:https://docplayer.fi/1950703-Katsaustyottomyyden-ja-terveyden-valisiin-yhteyksiin. html>. Luettu 1.2.2019.

Hult, M., Lappalainen, K., Saaranen, T. K., Räsänen, K., Vanroelen, C. \& Burdorf, A. (2020) Health-improving interventions for obtaining employment in unemployed job seekers. Cochrane Database of Systematic Reviews 8 (1), 1-64. https://doi. org/10.1002/14651858.CD013152.pub2

Karjalainen V., Saikku P., Pasuri A. \& Seppälä A (2008) Mitä on aktiivinen sosiaalipolitiikka kunnassa? Näköalapaikkana työvoiman palvelukeskukset. Raportteja 20/2008. Helsinki: Stakes.

Kerätär R. (2016) Kun katsoo kauempaa, näkee enemmän. Monialainen työkyvyn ja kuntoutustarpeen arviointi pitkäaikaistyöttömillä. Oulu: Oulun yliopisto.

Kerätär R \& Karjalainen V. (2010) Pitkäaikaistyöttömillä on runsaasti hoitamattomia mielenterveyshäiriöitä. Suomen Lääkärilehti 45 (65), 36833690.

Koskinen, S. \& Martelin, T. (2013) Suomalaisten terveys, toimintakyky ja terveyserot. Teoksessa M. Sihto, H. Palosuo \& P. Topo, J. Vuorenkoski \& K. Leppo (toim.) Terveyspolitiikan perusta ja käytännöt. Helsinki: Terveyden ja hyvinvoinnin laitos, 56-67.

Kykyviisari (2019) [online]. <URL: https://sivusto. kykyviisari.fi/>. Luettu 26.3.2019.

Lappalainen, K. (2017a) Työttömien työelämävalmiuksien tukeminen - painopisteenä terveydenhuolto ja verkostoyhteistyö. Kuopio: Itä-Suomen yliopisto.

Lappalainen, K. (2017b) Työttömien työelämävalmiuksien tukeminen edellyttää tiivistä verkostoyhteistyötä terveydenhuollossa. Työelämän tutkimus 15 (3), 287-289.

Lappalainen K., Mattila-Holappa P., Yli-Kaitala K., Hult M. \& Räsnen K. (2018) Pisimpään työttömänä olleet käyttävät vähiten terveyskeskuksen palveluja. Lääkärilehti 42 (73), 2421-2428.

Malmberg-Heimonen, I., \& Vuori, J. (2005) Activation or discouragement - the effect of enforced participation on the success of job-search training. European Journal of Social Work 8 (4), 451-467. https://doi.org/10.1080/13691450500314178
Mattila-Wiro P. \& Tiainen, R. (2019) Kaikki mukaan työelämään. Osatyökykyisille tie työelämään (OTE) kärkihankkeen tulokset ja suositukset. Luonnos. Helsinki: Sosiaali- ja terveysministeriö. Miller, D. S. \& Willson, R. R (1998) Individual differences in Machiavellianism as a mix of cooperative and exploitative strategies. Evolution and Human Behavior 19 (3), 2003-2012. https://doi. org/10.1016/S1090-5138(98)00011-7

Niiranen, K., Hakulinen, H., Manninen P. \& Räsänen, K. (2014) Työttömien terveyspalvelujen kehittäminen - verkosto mahdollisuutena. Työelämän tutkimus 12 (1), 3-22.

Niiranen, K., Hakulinen, H., Huuskonen, M. S., Jahkola A. \& Räsänen, K. (2011) Työttömän työelämävalmiuksien tukeminen viranomaisverkostossa. Sosiaalilääketieteellinen aikakauslehti 48 (1), $38-52$.

OECD (2017) State of Health in the EU. Suomi. Maan terveysprofili. [online].<URL: https://ec.europa. eu/health/sites/health/files/state/docs/chp_fi_ finnish.pdf>. Luettu 1.2.2019.

Oivo, T. \& Kerätär R. (2018) Selvityshenkilöiden raportti. Osatyökykyisten reitit työllisyyteen - etuudet, palvelut, tukitoimet. Helsinki: Sosiaalija terveysministeriö.

Patton M. Q. (1997) Utilization-Focused Evaluation. The New Century Text. Thousand Oaks, CA: Sage. Patton, M. Q. (2010) Developmental Evaluation. Applying Complexity Concepts to Enhance Innovation and Use. New York, NY: Guilford.

Peltola, U. \& Vuorento, M. (2007) Juurruttamisen edistäjät ja estäjät. Kokemuksia työllistymispalvelujen kehittämishankkeista. Työselosteita 33. Helsinki: Kuntoutussäätiö.

Saari, E., Hyytinen, K. \& Lähteenmäki-Smith, K. (2008) Kehittävä vaikuttavuusarviointi menetelmänä tutkimus- ja kehitystoiminnan suuntaamisessa ja oppimisessa. Hallinnon tutkimus 27 (1), 35-48.

Saari, E. \& Kallio, K. (2011) Developmental impact evaluation for facilitating learning in innovation networks. American Journal of Evaluation 32 (2), 227-245.

https://doi.org/10.1177/1098214010387658

Saikku P. \& Sinervo L. (2010) Työttömien terveyspalvelujen juurrutus. Valtakunnallisen PTT-hankkeen kokemuksia, arviointitutkimuksen tuloksia ja kansallisia suosituksia. Raportti 42. Helsinki: Terveyden ja hyvinvoinnin laitos 
Saikku, P. (2010) Perusterveydenhuollot ja työttömien palvelut. Työttömien terveystarkastukset ja -palvelut kunnissa. Helsinki: Terveyden ja hyvinvoinnin laitos.

Saikku P. (2012) Työttömien terveyspalvelun jatkuvuus. PTT-hankkeen seurantatutkimuksen tuloksia hankekunnissa. Raportti 15. Helsinki: Terveyden ja hyvinvoinnin laitos.

Sinervo, L. (2009) Pitkäaikaistyöttömien terveyshanke. Kehittämisvaiheen loppuraportti ja paikalliset toimintamallit. Raportti 23. Helsinki: Terveyden ja hyvinvoinnin laitos.

Sinervo, L. \& Hietapakka, L. (2013) Työpaperi. Työttömien terveyspalvelut. Valtakunnallisen terveyskeskuskyselyn 2013 tulokset. Työpaperi. Helsinki: Terveyden ja hyvinvoinnin laitos.

STM (2011) Sosiaalisesti kestävä Suomi 2020. Sosiaali- ja terveyspolitiikan strategia. [online]. <URL:http://stm.fi/strategia>. Luettu 16.10.2019.

Taipale, I. (2013) Työttömät ja terveydenhuolto. Duodecim 129 (21), 2204-2205.

TEM, STM (2019) Eduskuntaryhmien yhteinen kannanotto: Voimavarat työkyvyn ja työllistymisen tukemiseen. [online]. <URL: https://valtioneuvosto.fi/documents/1271139/12039326/Edus kuntaryhmien+kannanotto+työkyky+ja+työllist ymisen+tuki+050219.pdf/59fece7e-9fc8-85b72d37-f4c02772a0c1/Eduskuntaryhmien+kanna notto+työkyky+ja+työllistymisen+tuki+050219. pdf.pdf>. Luettu 18.2.2019.

Terveydenhuoltolaki. Suomen säädöskokoelma 1326/2010. [online]. <URL:https://www.finlex. fi/fi/laki/ajantasa/2010/20101326>. Luettu 21.1.2019.

Vartiainen, P. (2001) Intressiryhmät evaluointiprosessissa. Metodologista pohdintaa monitahoarvioinnin avulla. Hallinnon tutkimus 20 (1), 29-39.
Vartiainen, P. (2003) The substance of stakehoder evaluation: Methodological discussion. International Journal of Public Administration 26 (1), 29-46.

https://doi.org/10.1081/PAD-120018291

Vartiainen, P. (2007) Etukäteisarviointi voi auttaa tulevaisuuteen varautumisessa. Hallinnon tutkimus 26 (4), 1-2.

Virtanen, P. (1999) Verkostoista voimaa? Teoksessa Virtanen P. (toim.) Verkostoituva asiakastyö. Helsinki: Kirjayhtymä.

Vuokko A., Juvonen-Posti, P. \& Kaukiainen, A. (2012) Työttömän toiminta- ja työkyvyn hyvä arviointikäytäntö terveydenhuollossa. [online]. <URL: http://urn.fi/URN:NBN:fi-fe201703315915 >. Luettu 14.1.2019.

Vuori, J., Price, R., Mutanen, P, \& Malmberg-Heimonen, I. (2005) Effective group training techniques in job-search training. Journal of Occupational Health Psychology 10 (3), 261-275. https://doi.org/10.1037/1076-8998.10.3.261

Vuori, J. \& Toikkanen, J. (2008) Syrjäytymisen ehkäisy sosiaalisena innovaationa - esimerkkinä Työhön-menetelmä. Teoksessa J. Saari (toim.) Sosiaaliset innovaatiot ja hyvinvointivaltion muutos. Helsinki: Sosiaali- ja terveysturvan keskusliitto, 192-215.

Zammuto, R. (1984) Coping with disciplinary fragmentation. Journal of Management Education 2 (9), 30-37. https://doi. org/10.1177/105256298400900205

Åhs, A. M. H \& Westerling, R. (2006) Health care utilization among persons who are unemployed or outside the labour force. Health Policy 78 (23), 178-193.

https://doi.org/10.1016/j.healthpol.2005.10.010 